\title{
NESTING BIOLOGY AND DEFENSIVE BEHAVIOR OF MISCHOCYTTARUS (MONOCYTTARUS) MEXICANUS CUBICOLA (VESPIDAE:POLISTINAE)*
}

\author{
By Henry R. Hermann and Jung-Tai Chao \\ Department of Entomology, University of Georgia, \\ Athens, Georgia 30602
}

\section{INTRODUCTION}

Mischocyttarus mexicanus (de Saussure) is one of two species in this genus that occurs in the U.S. (Krombein et al., 1979). This genus is primarily Neotropical, being treated taxonomically by Bequaert (1933), Richards $(1945,1978)$ and Zikán (1935, 1949).

Litte $(1977,1979)$ described the biology of $M$. mexicanus in Florida and $M$, flavitarsis (de Saussure) in Arizona. $M . m$. mexicanus is found in Texas, Mexico and other parts of Central America. M. m. cubicola to date has been found in Georgia, Florida, Alabama, Cuba and the Bahamas (Krispyn and Hermann, 1977; Krombein et al., 1979).

Litte's study of the nesting biology and behavior of $M . \mathrm{m}$. cubicola (Litte, 1977, then described as M. mexicanus) was carried out at Archbold Biological Station at Lake Placid in southern Florida (Highlands County) where weather conditions allowed the wasps to nest throughout the winter. Our primary study area in Georgia had a more temperate climate where a 3 to 4 month hibernation period was necessary.

Sapelo Island, a 14-mile-long barrier island in McIntosh County, Georgia, consists of Holocene and Pleistocene deposits (Duncan, 1982). There is no official weather station on Sapelo Island. However, the average annual rainfall from 1944 to 1964 at McKinnon Airport on the southern end of St. Simons Island, about 7 miles south of Sapelo, was $134.6 \mathrm{~cm}$, with half of this falling during a 4-month period from June to September.

Mean minimum temperature for the coldest months was about $6.1^{\circ} \mathrm{C}\left(43^{\circ} \mathrm{F}\right)$. Temperatures as low as $0^{\circ} \mathrm{C}\left(32^{\circ} \mathrm{F}\right)$ occur only 15 days of the year. The lowest recorded temperatures were $-10^{\circ} \mathrm{C}$

${ }^{\circ}$ Manuscript received by the editor February 6, 1984. 
$\left(14^{\circ} \mathrm{F}\right)$ in December, 1962, and $-7.8^{\circ} \mathrm{C}\left(18^{\circ} \mathrm{F}\right)$ in February, 1958. Mean daily maximum temperature during the summer was under $32.2^{\circ} \mathrm{C}\left(90^{\circ} \mathrm{F}\right)$, only 49 days per year having a maximum of $32.2^{\circ} \mathrm{C}$ or above. The highest recorded temperature was $38.9^{\circ} \mathrm{C}\left(102^{\circ} \mathrm{F}\right)$ in June, 1950.

The purpose of this paper is to report the general nesting biology and defensive behaviors of $M . m$. cubicola at Sapelo Island.

\section{Materials ANd Methods}

Four trips were made to Sapelo Island (fall of 1982; late winterearly spring, 1983; June 9-12, 1983, August 23-30, 1983), one to Patterson Island, Ga. (adjacent to Sapelo) (June 11, 1983), one to Orlando, Polk County, Fla. (Aug. 7, 1983) and one to Haines City, Polk County, Fla. (Aug. 5-8, 1983). Two of the trips to Sapelo Island were preliminary surveys of the island while the later trips to Sapelo and the other three study areas revealed nests in various stages of development.

When an active nest was found, an attempt was made to provoke adults to defend by prodding them with the tip of a pen or comparable instrument. Defensive behaviors were video taped (Hitachi VT-650A VTR and VK-C600 color camera) during August so that they could be examined closely and repeatedly. Due to their readiness to escape under provocation in the early nesting season (June), some adults were lost. Following a study of their defensive behaviors, the nest and remaining adults were taken.

Nest contents and information on attending adults were later recorded. A comparison between paper surfaces of young and older nests was made through the use of scanning electron microscopy. Parts of nests were removed and adhered to specimen stubs with double-stick tape. They were coated with palladium-gold for 2 minutes in a Hummer sputter coater and observed with a Cambridge Mark II scanning electron microscope.

\section{Results AND Discussion}

\section{Nesting Sites}

Nests of $M . m$. cubicola were found on buildings, other manmade structures and on vegetation. Nests on the former were most often found on the wooden frames of windows, on the wooden support beams of metal roofed outbuildings and on the underside of 


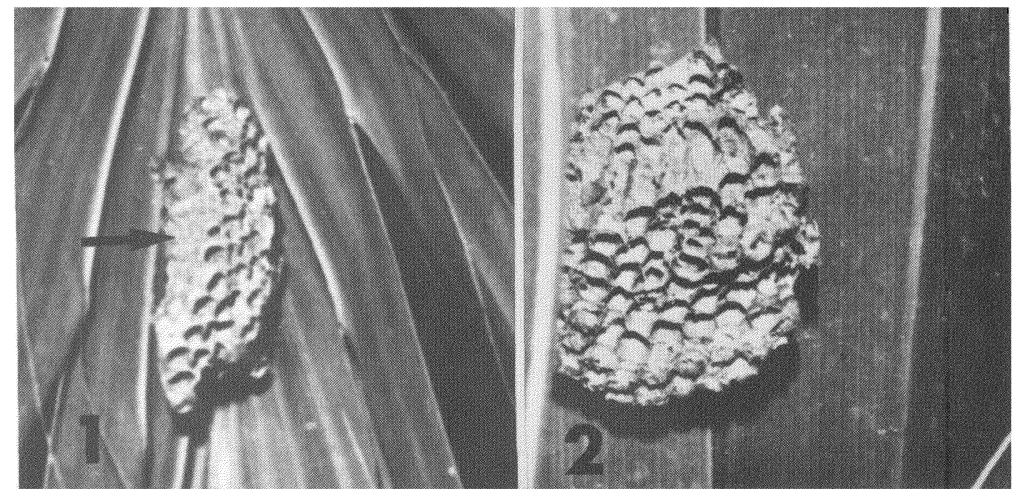

Figures 1 and 2. Nests of M. m. cubicola at Sapelo Island, showing the general structure and safety area on the back of the nest (arrow).

concrete arbors. Small (5-15 cells) uninhabited nests (Figs. 1 and 2) were numerous on the wooden frames of windows of the R. J. Reynolds home adjacent to the Marine Institute dormitory at the southern end of the island. Uninhabited nests were also found less abundantly on wooden structures of other buildings at the island's south end. Nest abandonment at these locations was partially due to occasional sprayings of pesticides. Three nests were found in metal and ceramic bell-like wind chimes in the Haines City, Polk County, Fla., location.

Nests on vegetation on Sapelo Island were found only on the underside of the leaves (Fig. 3) of the cabbage palm, Sabal palmetto (Walt.). This tree and Serenoa repens (Bartr.) (the common saw palmetto) (Fig. 4) are the most predominant members of the palm family, Arecaceae (= Palmae), found on Sapelo Island. One nest of this wasp was also collected from S. palmetto on Patterson Island, but nests were not found on buildings in that location. No nests were found on saw palmetto, Serenoa repens, on either island. In contrast to our findings, Litte (1977) found nests of this wasp almost exclusively on the leaves of Serenoa repens. Nests were found on cabbage palm on an island in a man-made lake near Orlando, Fla., and a single nest was found on the leaf of a plant in the genus Heliconia (Musaceae) at that location. Bequaert (1933) mentioned a nest found in Cuba that was built on Spanish moss (Tillandsia, Bromeliaceae) about six feet above the ground at the periphery of a swampy margin of a stream. 
Sabal palmetto (Fig. 3), most abundant on the south end of Sapelo Island, appears ideal for a nesting site because of the way in which mature leaves hang in a horizontal plane, each leaf offering a pair of nesting sites, one on each side of the midrib. Serenoa repens, on the other hand, has leaves that extend upward from the ground in a more-or-less vertical plane (Fig. 4). Such leaves offer very little protection from both weather and birds.

\section{Reproductive Potential}

Based on information from 10 nests, a single egg layer was apparently on each nest during the June 9-12 observation period (Table 1). This is based entirely on ovary size. Although escaping females were lost, the most gravid females of other polistine species (Hermann, unpublished) usually remain on the nest when provoked while less gravid females depart. Therefore, it is our opinion that each nest had a single egg layer. Only in one case (Nest \#4) a second female on the nest had other than small, non-reproductive ovaries, and they were developed but not large.

At least half of the nests found at Sapelo Island, and probably more, were in the predaughter (= preemergence) phase. Litte (1977) also found her nests at this stage with a single egg layer. Females other than the gravid queen on nest \#4 in which there were no pupae are considered to be cofoundresses. This supports the pleometrotic status of this subspecies as found earlier by Litte (1977). Our data (Table I) do no show a significant difference in wing length between the queens and non-queens $\left(\mathrm{X}^{2} 0.5(1)=3.841\right)$.

\section{Predation and Potential Predators}

A high degree of predation by birds of wasp nest immatures was apparent on Sapelo Island. Although bird species were not identified in this location, nests were often found shredded and abandoned, a condition characteristic of bird damage. Numbers of damaged nests were not recorded. Jeanne (1975), Richards and Richards (1951), and Turillazzi (1984) have stated that birds and ants are the most important predators of social wasps in general. Birds apparently are the most significant predators in temperate zones (Jeanne, 1975). Jeanne (1970) reported predation on Mischocyttarus by bats.

Litte (1977) reported seeing blue jays attacking nests of $M . m$. cubicola in south Florida and she listed the carolina wren, scrub jays, common yellowthroat, cardinal, thrashers, mockingbird and 


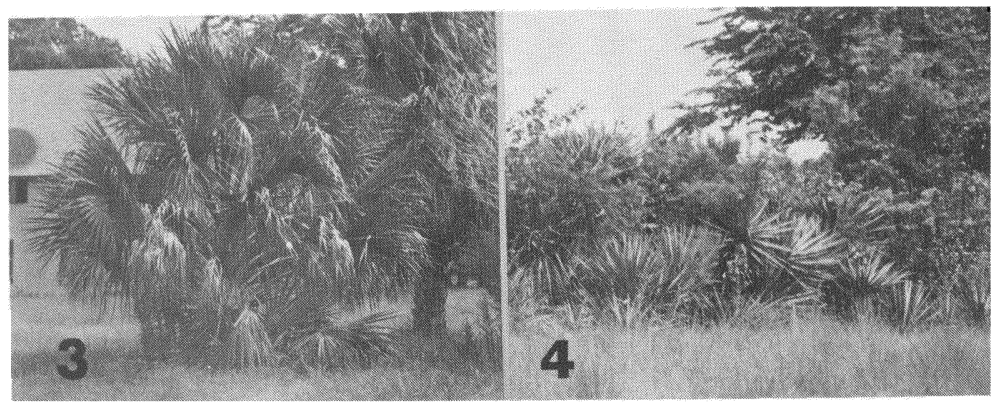

Figures 3 and 4. Plants found to be nesting sites for M. m. cubicola by us and by Litte (1977). 3, Sabal palmetto, showing draping nature of the leaves, making it an ideal site for nesting wasps. 4, Serenoa repens, showing the nature of growth so that leaves do not drape, making them a poor site for nests.

robin as potential vertebrate predators. She also pointed out that scrub jays and red headed woodpeckers are known predators of Polistes adults. Invertebrate predators of wasp immatures were Dorymyrmex flavopectus, Crematogaster ashmeadi, Pheidole floridana, Camponotus floridanus, and Monomorium floricola (Formicidae). Spiders were found to catch and feed on wasp adults. Starr (1981) reported blue jays and summer tanagers as possible polistine predators. Litte (1977) found that defense against vertebrate attack was ineffective, while defense against ants was effective in most cases. Polistine wasps are apparently free of most terrestrial predators while some vespines are heavily preyed upon by them (Preiss, 1967).

\section{Details of Nest Structure and Architectural Defense}

Of the ten nests that were collected between June 9 and June 12, 1983 (Table I), six had 15 cells or more. The average number of cells was $13.90(\mathrm{SD}=8.41)$. Although there is no information about colony growth rate at this time, it appears that most nest initiation occurred in May. Data collected from nests 1, 3, 5 and 7 (Table I) with less than 10 cells imply that either: 1) they were reinitiated after predation or 2) they were late initiators. Further study on these possibilities may give us a better understanding of the selection forces acting upon developing colonies. Most nests in June collections had a single female that dominated the face of the nest while other adult nest occupants spent much of their time on the 


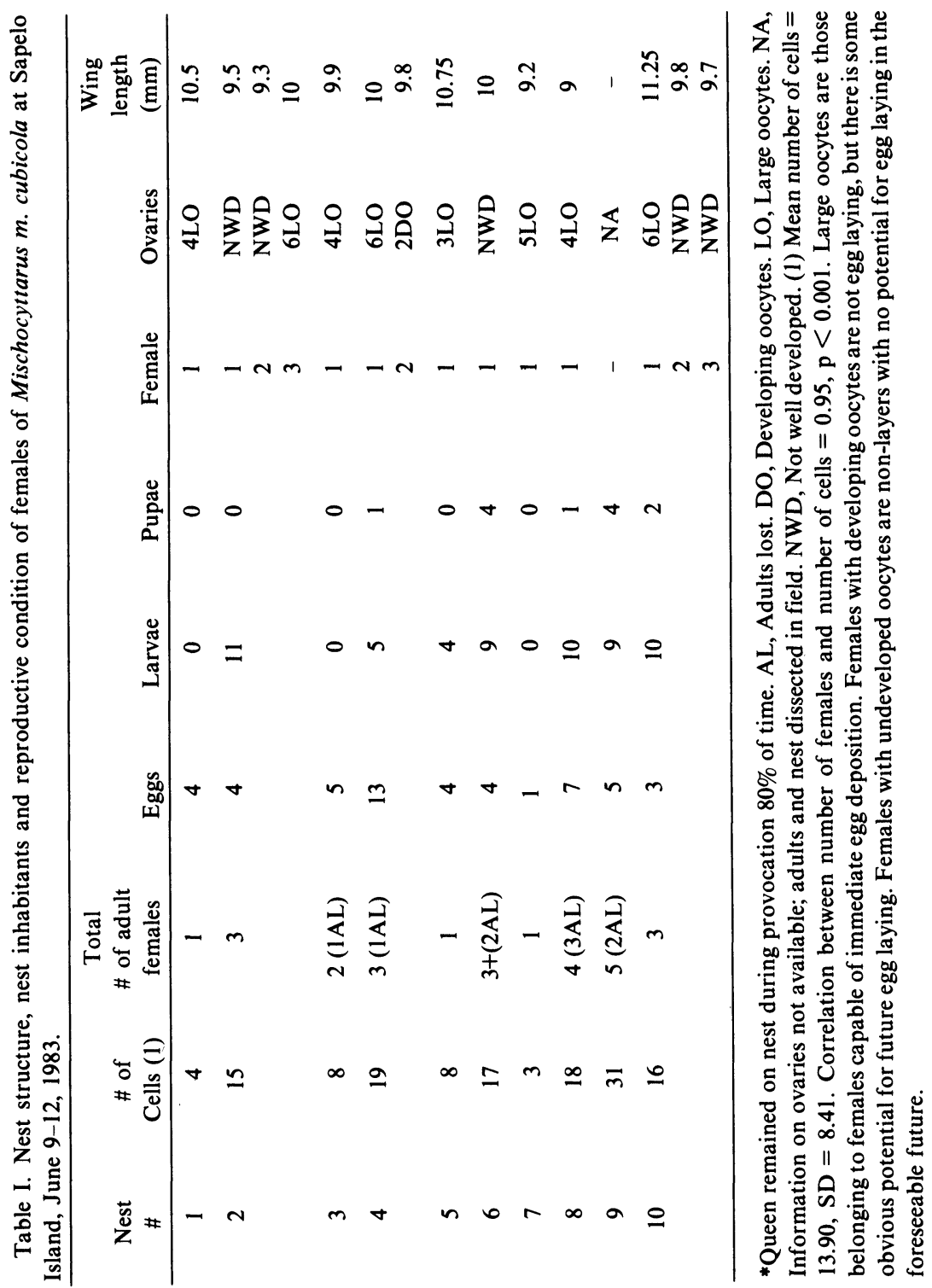


back of the nest. There is a significant positive correlation $(r=$ $0.095, p<0.001$ ) between the number of females and the number of cells in a nest (Table I).

Small nests that were relatively new were light gray in color, while larger nests were often a darker, brownish color. The walls of small, young nests were translucent and the outline of a larva could be seen inside. In addition, the paper was loosely made (Fig. 8) so that occasional holes existed in the cell walls. The loose appearance and light color of the paper indicated that very little if any head secretions were added other than what was necessary to adhere the layers together. Also, very little mandibular working of the paper was done by the wasps at this time. Both paper darkening and smoothing (Figs. 6 and 7) appear to commence between the 4-5 cell stage and the time of capping.

Cell cap darkening following spinning is done by adults. Freshly spun caps were whitish while those of older pupae had brownish colored wood particles adhering to them (Fig. 5). Darkening of the caps and the addition of wood particles blended the caps with the rest of the nest, making them cryptic. This is a primary defense (Edmunds, 1974).

Another primary defense is seen in the way in which most of the nests hang on their pedicels. Some are elongate, pendulous (Fig. 1), others more round in appearance (Fig. 2). Irrespective of shape, all were constructed with the nest back away from the direction of provocation. This is most apparent on nests constructed on buildings. This allows adults to retreat from provocation rather than defend.

Nests on Sabal palmetto often were horizontally elongate, following the available space on the underside of the leaf. Most successful nests were constructed under leaves that had additional folds which allowed further protection from birds. Nests found in bell-like wind chimes in Haines City, Florida, were exceptionally well protected. The bells, in effect, were analogous to the bag-like (calyptodomous) nests of arboreal vespines. Predation on these nests by birds would be difficult.

Similar and other forms of architectural defense have been reported from other social hymenopterous species by numerous individuals and has been reviewed by Hermann and Blum (1981). 

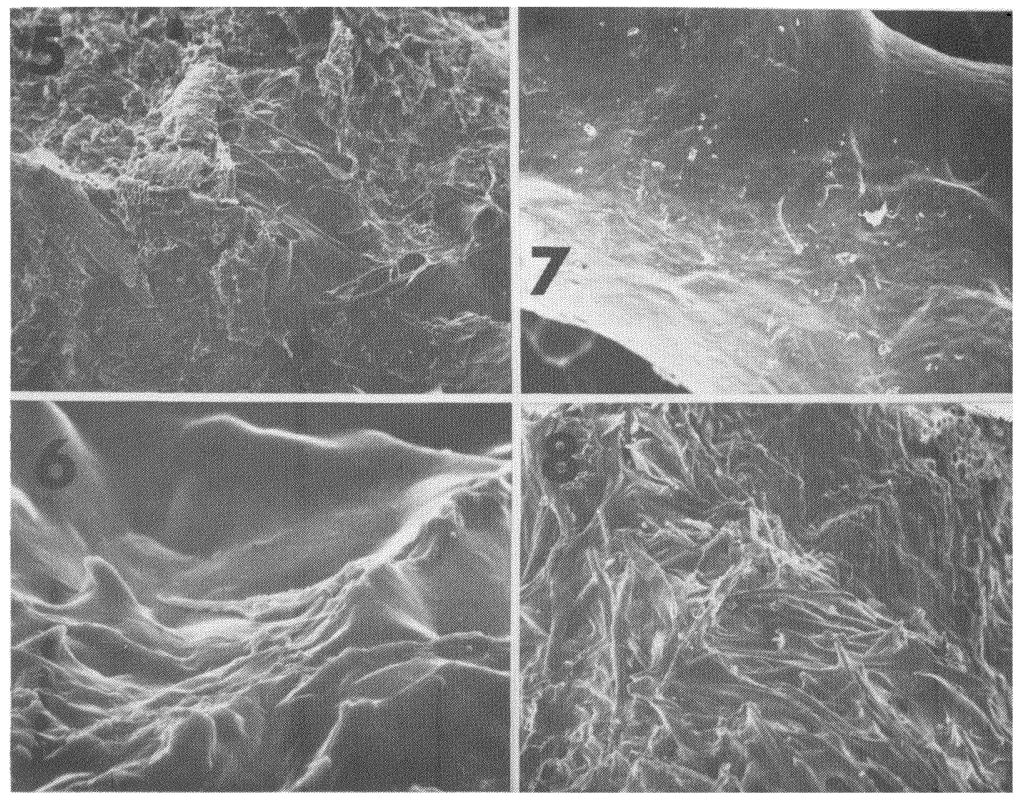

Figures 5-8. Scanning electron micrographs of paper from nests of $M . m$. cubicola. 5, Cap on cell of a late pupa (nest \#9, June collection, 31 cells), showing wood and other debris deposited by adult wasps, thus giving the cap a cryptic appearance $(50 X)$. 6, Paper on outside of same nest, showing its non-woody, wellworked surface $(500 \mathrm{X})$. 7, Pedicel of same nest, showing extremely smooth texture (100X). 8, Pedicel of smaller, newer nest (nest \#1, June collection, 44 cells), showing loose nature of woody constituents (100X).

\section{Defensive Behavior other than Architectural}

\section{Young Colonies}

Attack behavior as studied by numerous individuals and reviewed by Hermann and Blum (1981) appeared to be non-existent in this species during early colony life. However, a pseudoattack was elicited from wasps upon strong provocation. Strong provocation was carried out by tapping on the leaf upon which the nest was built or by actually touching the nest. Pseudoattack is defined as adult flight from the nest in the direction of the intruder. This differs from escape in which flight is not directed toward the intruder. Pseudoattack is readily demonstrated in other local polistines, e.g., 
Polistes annularis (Linnaeus) and P. exclamans (unpublished). We would classify pseudoattack as a very strong warning behavior. Pseudoattack was best demonstrated by $M . M$. cubicola in more mature colonies (found in August on Sapelo Island), while escape was more prevalent in younger colonies.

Other warning behaviors are as follows, some of which have been described by Jeanne (1972), Litte (1977, 1979), Starr (1981) and Windsor (1972) for this and other species of Mischocyttarus.

Defensive Posture-antennae forward, wings raised, body lifted and mandibles sometimes spread. Strong provocation was necessary to elicit this combination of behaviors in young nests. Litte (1979) reported that $M$. flavitarsis males and females both assume a defensive posture when disturbed.

Increased Movement on the Nest-increased movement gives the nest an agitated appearance. Increased provocation elicits increased movement by adult wasps and apparently lowers the threshhold for attack.

Wing Raising - generally with approximately an angle of $57^{\circ}$ $107^{\circ}$ between wings $(\bar{X}=84.6, \mathrm{SD}=13.7)$, and a mean angle of $38^{\circ}$ above the horizontal plane of the body. While wing raising is one of the first warning behaviors elicited in most polistines (Hermann and Blum, 1981; Starr, 1981; West Eberhard, 1969), most females of $M$. $m$. cubicola on young nests did not raise their wings unless they were strongly provoked. Wing raising also has been reported for $M$. drewseni by Jeanne (1972) and for M. m. cubicola by Starr (1981). Raised wings appear to have two separate positions, a smaller angle of separation (approximately $60^{\circ}$ ) for wasps that are weakly provoked and a greater angle of separation (approximately 90$100^{\circ}$ ) for wasps that are strongly provoked. However, there is considerable overlap in these two positions.

Wing Buzzing - a prolonged wing movement, not generally demonstrated in early colonies except under strong provocation. Wing buzzing was demonstrated by M. flavitarsis (Litte, 1979), but adults did not attack in the pre-emergence phase. Attack was prevalent following wing buzzing in the post-emergence phase, however.

Wing fluttering - sporadic rapid flapping of wings, of a much shorter duration than buzzing. Strong provocation was necessary to elicit this behavior in young nests. Wing fluttering frequencies may be found in Table III. 
Forward Jerking and Mandibular Pecking-a rapid movement forward and a biting at the object of intrusion. Pecking was also demonstrated in the absence of forward jerking. Although pecking behavior was easily elicited in a young colony, it appeared to be demonstrated in such cases almost entirely by the queen. Pecking is a behavior commonly used by adult females toward small hymenopterous parasitoid intruders. In $P$. annularis, forward jerking and pecking have been observed by us to chase and/or discard intruding ants from the nest. We witnessed such behavior in older colonies observed in August, 1983.

Backward Jerking-best demonstrated under strong provocation.

Abdominal Pumping-although abdominal pumping, a rhythymic extension and retraction of the gaster, is seen as normal behavior in all vespids, it appears to be exaggerated during provocation.

Abdominal twisting-this behavior was not evident on a young nest except under very strong provocation. However, when strongly provoked, most females of a young nest demonstrated this behavior as well as exaggerated abdominal pumping.

Movement to back of nest (retreat)-a behavior that was demonstrated upon continuous provocation. Even females that demonstrate warning behaviors move to the back of the nest upon continuous provocation.

Escape-this is readily demonstrated in young colonies under provocation. In fact, it is difficult to elicit defensive behaviors in young colonies and collect all of the adults because of their readiness to escape. Nest departure by adults of more mature colonies is expressed more as pseudoattack in which case adults return to the nest after a short erratic flight. Adults in escape flights do not return for a longer period of time.

Leg waving - this behavior was demonstrated on occasion in young colonies and readily in mature ones. Although females of young colonies are reluctant to leg wave unless strongly provoked, this behavior was less difficult to elicit in a young colony than were some of the other behaviors. Leg waving frequencies may be found in Table III.

None of the behaviors appeared to be demonstrated in a particular sequence, and many of the behaviors were demonstrated by some individuals and not by others. Escape and retreat were the most dependable behaviors in young (preemergence) colonies. 
Escape and pseudoattack also occur in colonies of $P$. annularis, $P$. exclamans and $P$. fuscatus during the preemergence period (unpublished).

\section{Mature Colonies}

A mature colony is defined here as one in which daughters have emerged (post-emergence colony), and defensive behaviors are readily expressed, many of them requiring little provocation. Although there is very little difference in nest size between nest 9 of Table I (June collection) and nest 1 of Table II (August collection), defensive behavior in August was considerably more evident. The mean number of cells of the 4 nests collected in August (Table II) was $72.5(\mathrm{SD}=46.3)$. Few males were found to have emerged (nests 2, 4, Table II). By comparing the colonies in June and August, we noticed that not only the colony structure changes significantly but the defensive behaviors demonstrated by colony members are also quite different. The change in defensive behaviors could be: 1) a seasonal, physiological change in adults, or 2) related to investment, such as higher total number of immatures, more older larvae and pupae, and more nesting material.

There was an apparent synchrony of movement among warning females toward a moving intruder, due in part to a periodic hooking together of their tarsi and legs. This behavior is difficult to describe and would have gone unnoticed had it not been recorded on video tape and played back at a slower speed.

A sequence of wing raising, leg waving and wing fluttering was readily apparent. Under strong provocation, wing fluttering, leg waving and exaggerated abdominal pumping were demonstrated simultaneously. The frequency of movement in leg waving was

Table II. Nest structure and inhabitants of nests of Mischocyttarus m. cubicola at Sapelo Island, Georgia, and Haines City, Florida, August 5-8, 23-30, 1983.

\begin{tabular}{lcccccc}
\hline \multicolumn{7}{c}{ Adults } \\
Nest \# & \# of Cells & Males & Females & Eggs & Larvae & Pupae \\
\hline l(HC) & 40 & 0 & 14 & 8 & 22 & 10 \\
2(HC) & 42 & 1 & 15 & 8 & 13 & 14 \\
$3(\mathrm{HC})$ & 56 & 0 & 7 & 23 & 21 & 1 \\
$4(\mathrm{~S})$ & 152 & 3 & 27 & 16 & 60 & 38 \\
\hline
\end{tabular}

HC, Haines City, Florida; S, Sapelo Island, Georgia. Mean number of cells $=72.5$ (SD $=46.3$ ). 
Table III. Statistical Analysis of Frequencies of Readily Expressed Warning Behaviors in Colonies of M. m. cubicola (1)

\begin{tabular}{cccc}
\hline $\begin{array}{c}\text { Exp. } \\
\#\end{array}$ & $\begin{array}{c}\text { Leg Waving } \\
\text { Movements/Sec. }\end{array}$ & $\begin{array}{c}\text { Wing Fluttering } \\
\text { Beats/Sec. }\end{array}$ & $\begin{array}{c}\text { Pseudoattack } \\
\text { Flight Time } \\
\text { in Sec. }\end{array}$ \\
\hline 1 & 8.3 & 5.6 & 2.7 \\
2 & 9.1 & 6.3 & 3.3 \\
3 & 7.7 & 6.7 & 1.6 \\
4 & 9.1 & 6.3 & 1.6 \\
5 & 9.1 & 5.3 & 5.8 \\
6 & 7.1 & 7.7 & 3.7 \\
7 & 7.7 & 5.3 & 2.8 \\
8 & 9.1 & 5.6 & 3.7 \\
9 & 7.1 & 6.3 & 9.0 \\
10 & 7.7 & 6.7 & 1.6 \\
\hline X, SD, CV & $\mathrm{X}=8.2$ & $\mathrm{X}=6.18$ & $\mathrm{X}=4.18$ \\
& $\mathrm{SD}=.801$ & SD $=.72$ & SD $=2.5$ \\
& $\mathrm{CV}=0.64$ & $\mathrm{CV}=.51$ & $\mathrm{CV}=0.60$ \\
\hline
\end{tabular}

(1) Behaviors were recorded from different females.

7.1-9.1/second $(\mathrm{X}=8.2, \mathrm{SD}=.801, \mathrm{CV}=.64)($ Table III). The frequency of wing fluttering was 5.3-7.7/ second $(\bar{X}=6.2, S D=.72$, $\mathrm{CV}=.51)$. We found no correlation $(\mathrm{r}=.07)$ between movement frequencies of leg waving and wing fluttering in different females (Table III). It appeared to us that a threshold had to be reached before leg waving or wing fluttering would come about, and once this threshold was reached, the duration of each behavior was dependent upon the degree of continued stimulus. However, very little variation appeared to exist in the frequencies of these behaviors in relation to the excitedness of the colony (Table III).

Pseudoattack by multiple females was easily elicited. Yet, attempts at stinging were relatively rare. Departing females flew in the direction of intrusion but most often culminated their pseudoattack with an erratic, vertically undulating flight in their return to the nest. In recording the duration of 10 randomly selected pseudoattack flights, each flight usually lasted only 1.6-9.0 seconds $(\mathrm{X}=4.2, \mathrm{SD}=2.5, \mathrm{CV}=0.60)($ Table III).

Behavior after returning to the nest often involved rapid walking on the nest face in apparent examination of the nest surface and its coinhabitants. The checking of cells and cell contents was not as 
apparent as has been reported by Starr (1981) for some other polistine species. At times, females would spin in place on the nest immediately upon returning from a pseudoattack flight. Spinning is described as a rapid turning of the body throughout a small radius of movement. Also, post-attack grooming is sometimes evident.

Nests 1-3 from Haines City, Florida, reacted to provocation much like nest 4 (Table II), even through there was a considerable difference in nest size. One apparent behavioral difference existed. Nests from Haines City were adjacent to one another in metal and ceramic bell-like wind chimes. When strongly provoked, adults that left the nest in pseudoattack at times returned to a neighboring nest rather than to their own and rapidly moved around the nest face. Observing this indicates to us that possibly the three nests were initiated by siblings. We have observed similar behavior in Polistes annularis. Comparisons between June and August nests point out that defensive behavioral changes occur in $M . m$. cubicola as a function of time. This is also true for $P$. annularis, $P$. fuscatus and $P$. exclamans (unpublished) and appears to be widely recognized for other vespid species (Hermann and Blum, 1981). The major differences occur in the defensive attitude of eusocial wasps between the pre- and post-emergence periods.

\section{SUMMARY}

Mischocyttarus mexicanus cubicola on Sapelo Island, Georgia, nests on buildings, other man-made structures and on the underside of leaves of the Cabbage Palm, Sabal palmetto. Although defensive behaviors expressed in young colonies at first appear to be poorly demonstrated in this subspecies, they include nest architecture and, under strong provocation, pseudoattack and subsequent erratic flight, general nest excitability, defensive posture, wing raising, wing buzzing, wing fluttering, forward jerking, mandibular pecking, backward jerking, abdominal pumping, abdominal twisting, retreat and escape. None of the warning behaviors were demonstrated in young colonies in a consistent manner or in a particular sequence. The most consistent behaviors in young colonies were retreat and escape, whereas in mature colonies all of the warning behaviors recorded for young colonies were expressed readily and in a predictable sequence. 


\section{ACKNOWLEDGEMENTS}

We would like to extend our appreciation to the following individuals for their warm hospitality during this investigation: Mr. and Mrs. Ralph Talarico, Haines City, Florida; Mr. and Mrs. Fred Woodward, Patterson Island, Georgia. Also, we would like to thank the University of Georgia Marine Institute at Sapelo Island for their support in this project.

BequaerT, J.

\section{REFERENCES}

1933. The Nearctic social wasps of the subfamily Polybiinae (Hymenoptera: Vespidae). Entomol. Amer. 13:87-148.

DunCan, W. H.

1982. Vegetation of Sapelo Island. Georgia Dept. Nat. Res. Publ. 75 pp. EdMUNDS, M.

1974. Defence in Animals. Harlow, Essex: Longman, 357 pp.

Hermann, H. R. and M. S. Blum

1981. Defensive mechanisms in the social Hymenoptera. [In] Social Insects, H.

JEANNE, R. L. R. Hermann, ed., Academic Press, New York, vol. 2, pp. 77-197.

1970. Chemical defense of brood by a social wasp. Science 168:1465-1466.

1972. Social biology of the Neotropical wasp Mischocyttarus drewsenii. Bull. Mus. Comp. Zool., Harvard Univ. 144:63-150.

1975. The adaptiveness of social wasp nest architecture. Q. Rev. Biol. 50:267-287.

Krispyn, J. W. AND H. R. HermanN.

1977. The social wasps of Georgia: Hornets, yellowjackets, and polistine paper wasps. USDA Agric. Res. Bull. 207, 39 pp.

Krombein, K. V., P. D. Hurd, Jr., D. R. Smith, and B. D. Bucks.

1979. Catalog of Hymenoptera in America North of Mexico. Smithsonian Inst. Press, Washington, D. C. vol. 2, p. 1516.

LITTE, M.

1977. Behavioral ecology of the social wasp Mischocyttarus mexicanus. Behav. Ecol. Sociobiol. 2:229-246.

1979. Mischocyttarus flavitarsis in Arizona: Social and nesting biology of a polistine wasp. Zts. Tierpsychol. 50:282-312.

Preiss, F. J.

1967. Nest site selection, microenvironment and predation of yellowjacket wasps, Vespula maculifrons (Buysson) (Hymenoptera, Vespidae) in a decidous Delaware woodlot. M. Sc. thesis, Univ. Delaware, $81 \mathrm{pp}$.

RICHARDS, O. W.

1945. A revision of the genus Mischocyttarus de Saussure (Hymen., Vespidae). Trans. R. ent. Soc. Lond. 95:295-462.

1978. The Social Wasps of the Americas. Fletcher and Son Ltd, Norwich. 
RICHARDS, O. W. AND M. J. RICHARDS.

1951. Observations on the social wasps of South America (Hymenoptera: Vespidae). Trans. R. ent. Soc. Lond. 102:1-170.

SNELLING, R. M.

1981. Systematics of social Hymenoptera. [In] Social Insects, H. R. Hermann, ed., Academic Press, New York, vol. 2, pp 369-453.

STARR, C. $K$.

1981. Defensive tactics of social wasps. Doc. Dis., Univ. Georgia, Athens, 108 pp.

TURILlazzI, S.

1984. Defensive mechanisms in Polistes wasps. [In] Defensive Mechanisms in Social Insects, H. R. Hermann ed., Praeger Scientific, New York (in press).

West EBerhard, M. J.

1969. The social biology of polistine wasps. Univ. Mich. Mus. Zool. Misc. Publ. 140:1-101.

WINDSOR, D. M.

1972. Nesting association between two Neotropical Polybiine wasps (Hymenoptera, Vespidae). Biotropica 4:1-3.

ZIKÁN, J. F.

1935. Die sozialen Wespen de Gettung Mischocyttarus Saussure, nebst Beschreibung von 27 neuen Arten (Hym., Vespidae) Archos. Inst. Biol. Sao Paulo 1:143-203.

1949. O genero Mischocyttarus Saussure (Hymenoptera, Vespidae), con a descripao de 82 species novas. VBoln. Parq. nac. Itatiaia 1:1-251. 

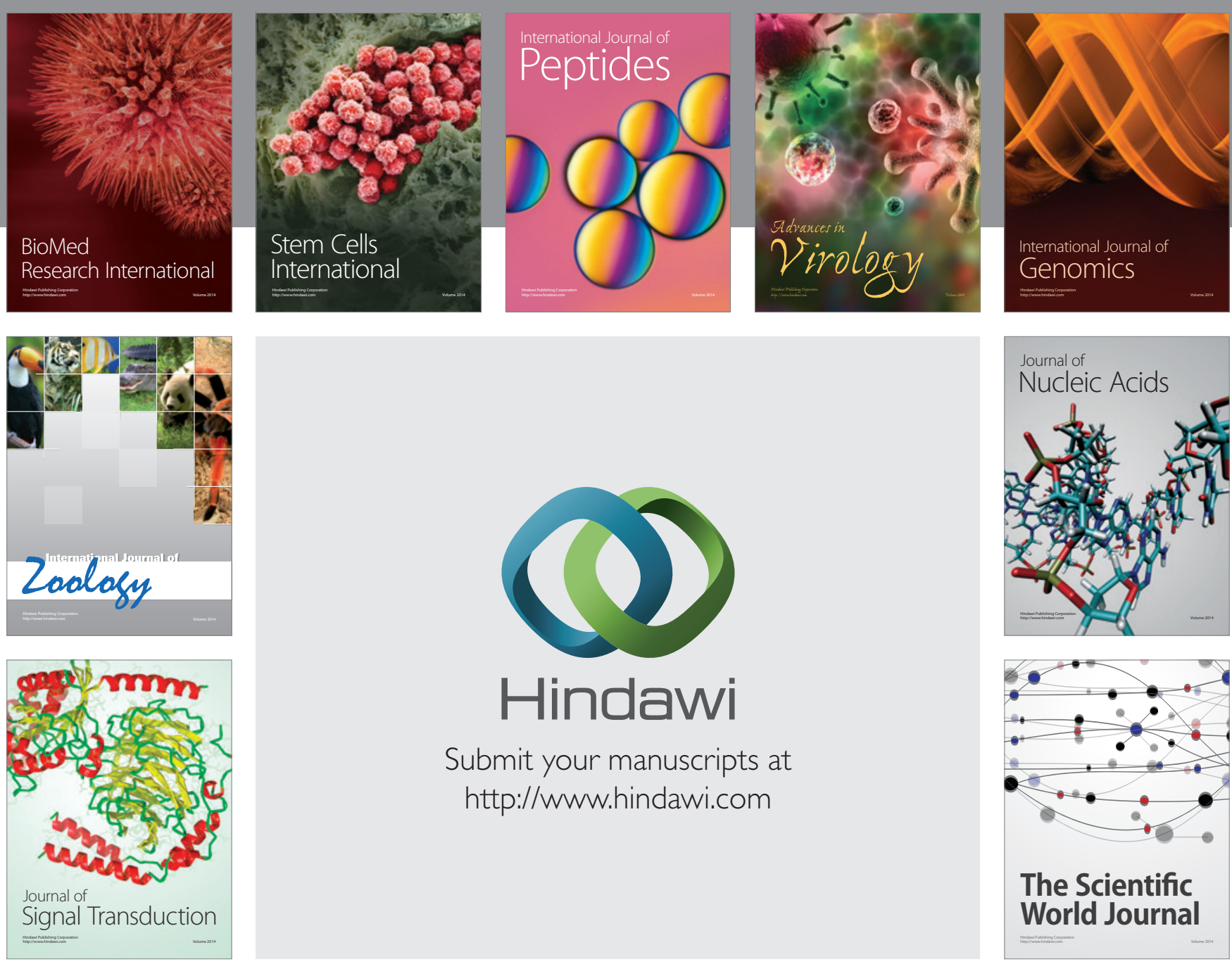

Submit your manuscripts at

http://www.hindawi.com
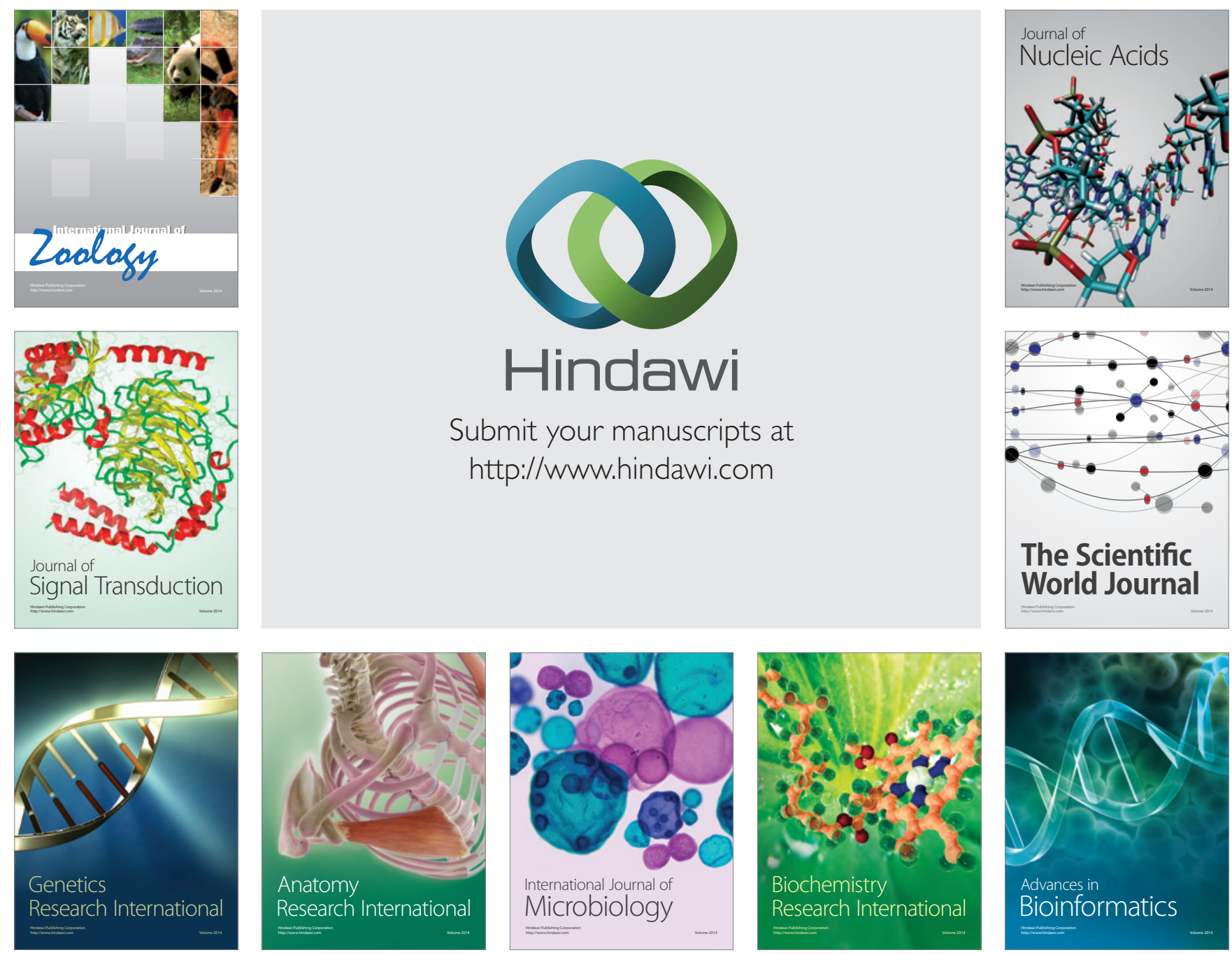

The Scientific World Journal
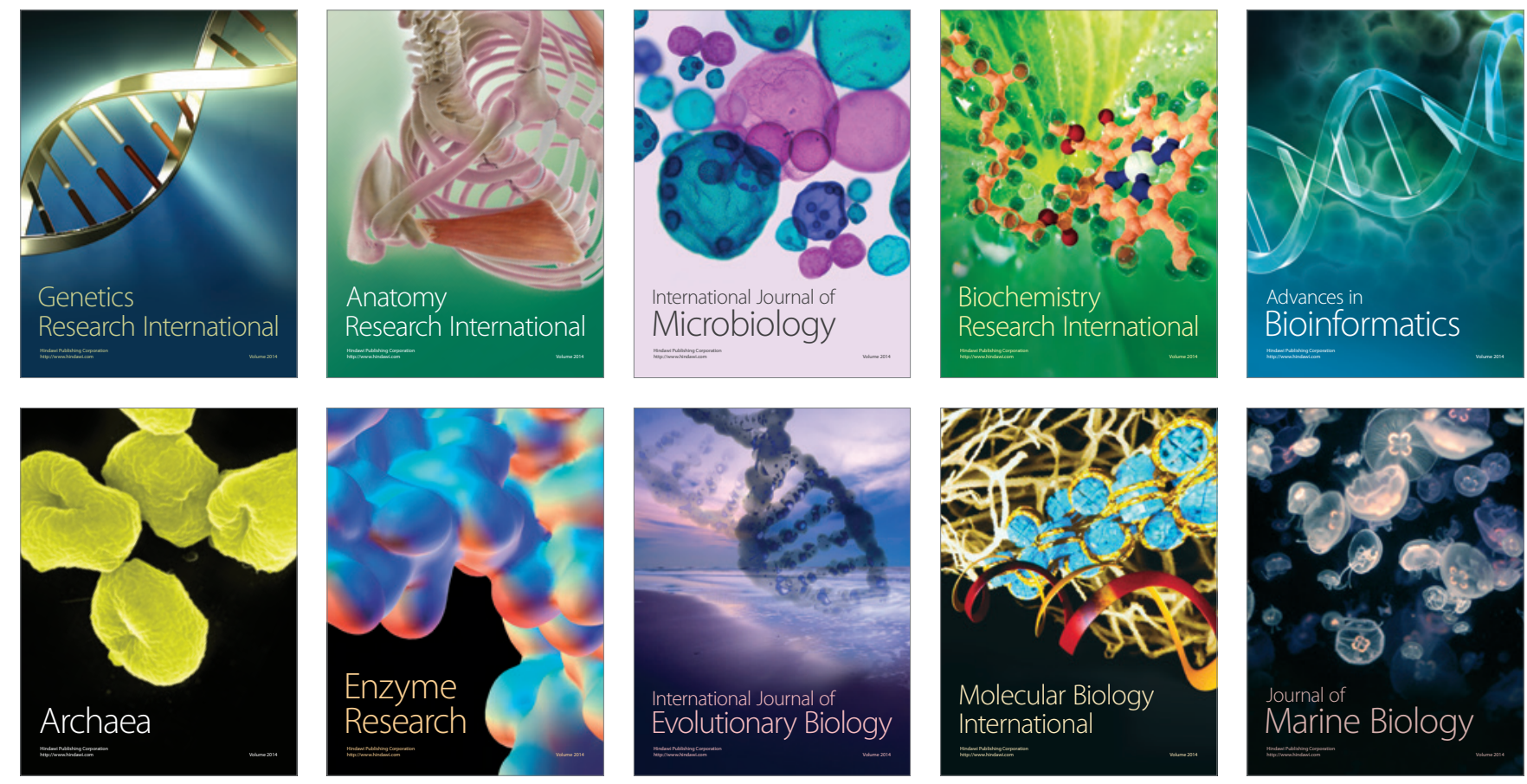